\title{
Impact of particulate organic matter composition and degradation state on the vertical structure of particle- associated and planktonic lacustrine bacteria
}

\author{
Krista E. Köllner ${ }^{1,2}$, Dörte Carstens ${ }^{1,2}$, Carsten J. Schubert ${ }^{1}$, Josef Zeyer ${ }^{2}$, \\ Helmut Bürgmann ${ }^{1, *}$ \\ ${ }^{1}$ Eawag, Swiss Federal Institute of Aquatic Science and Technology, \\ Department of Surface Waters - Research and Management, 6047 Kastanienbaum, Switzerland \\ ${ }^{2}$ Institute of Biogeochemistry and Pollutant Dynamics, ETH Zürich, 8092 Zürich, Switzerland
}

\begin{abstract}
In order to determine how concentration, composition, and degradation states of particulate organic matter (POM) influence lacustrine bacteria, we analyzed changes in bacterial community (BC) structure and total bacterial cell abundance throughout the water columns of 2 contrasting deep lakes in Switzerland. Lake Brienz is oligotrophic and fully oxic while Lake Zug is eutrophic and partially anoxic. The community composition of the particle-associated $(>5 \mu \mathrm{m})$ and free-living $(>0.2,<5 \mu \mathrm{m})$ bacteria was analyzed by automated ribosomal intergenic spacer analysis (ARISA). Cluster analysis showed that the lakes comprised distinct BCs. However, the BCs of both lakes were structured with depth. Although particulate amino compounds appeared to impact the number of ARISA-operational taxonomic units of the particle-associated BCs throughout the lake water columns, the compositional dynamics of this bacterial fraction were affected more strongly by the sampling date and physico-chemical parameters, such as $\mathrm{pH}$. For the free-living BCs, the chlorin index $(\mathrm{CI})$, an indicator for the degradation state of primary produced POM, appeared to significantly impact the vertical community shifts. The vertical changes of the total bacterial cell abundance were also significantly determined by the CI and by shifts in particulate amino compounds. The present study shows that not only bulk environmental parameters but also POM composition and degradation state shape the abundance and composition of lacustrine BCs.
\end{abstract}

KEY WORDS: Lake · Freshwater · Degradation index · Microbial community · Variation partitioning $\cdot$ Environmental factors $\cdot$ Amino sugars $\cdot$ Amino acids

\section{INTRODUCTION}

One of the big challenges in aquatic microbial ecology is to derive the most important environmental factors that structure the bacterial community composition (BCC) and to relate the BCC dynamics to specific ecosystem functions. This is a prerequisite for creating predictive aquatic ecosystem models. Culture-independent molecular methods have facilitated the characterization of bacterial communities (BCs) in lakes over the last decades (Hiorns et al.
1997, Casamayor et al. 2000, Lindström 2000, Van Der Gucht et al. 2001, Zwart et al. 2002, Yannarell \& Triplett 2004, Newton et al. 2011). Several studies have determined environmental factors that constrain the BCC in these freshwater systems. For instance, the availability of nutrients and organic carbon (Yannarell \& Triplett 2004) and the physicochemical characteristics of a lake, such as $\mathrm{pH}$, temperature (Methé \& Zehr 1999, Lindström et al. 2005, Rösel et al. 2012), and oxygen concentrations (Shade et al. 2008), have been reported to shape the BCC. 
Biotic factors such as bacterivorous grazing, phage dynamics, and phytoplankton succession have also been demonstrated to determine BCC (Jürgens et al. 1999, Šimek et al. 2001, Kent et al. 2004, 2006, Salcher et al. 2011, Zeng et al. 2012).

A crucial function of aquatic bacteria is the degradation of organic matter and the resulting recycling of nutrients and carbon (Azam et al. 1983, Sherr \& Sherr 1991). Of the planktonic primary production, 30 to $60 \%$ is mineralized by heterotrophic bacteria (Biddanda et al. 1994, Del Giorgio et al. 1997). In aquatic environments, organic matter is divided into dissolved organic matter (DOM) and particulate organic matter (POM). In lakes, the POM fraction is estimated to contribute approximately $10 \%$ of the total organic matter and mainly consists of polymeric, high molecular weight compounds (Siuda \& Chróst 2002). Amino sugars (ASs) and amino acids (AAs) are building blocks of a number of these biopolymers. Among these biopolymers are proteins, polysaccharides exuded from phytoplankton (Giroldo et al. 2003), and chitin, which is synthesized by diverse aquatic organisms (crustaceans, fungi, diatoms).

ASs and AAs have been used to indicate the quality and origin of POM. For instance, the relative abundance of specific particulate ASs and AAs can indicate the degradation state of POM (Lee \& Cronin 1984, Haake et al. 1992, Dauwe \& Middelburg 1998). In a previous study on the lakes studied here (see below), the ratios between the particulate ASs glucosamine (GlcN) and galactosamine (GalN) showed a strong decline below the zone of primary production (Carstens et al. 2012). This finding was related to a shift from the AS signature of organisms of higher trophic levels in the euphotic zone towards the signal of heterotrophic microorganisms and progressing degradation of POM. Relative to ASs, AAs are preferentially utilized and, thus, the ratios between AAs and ASs decrease during microbial decomposition (Dauwe \& Middelburg 1998, Davis et al. 2009).

A different measure for the degradation state of primary produced POM is the chlorin index (CI) introduced by Schubert et al. (2005). The CI is based on the oxidation state of chlorins, the degradation products of chlorophyll. It increases for degraded material and has proven to be a powerful tool for characterizing the initial stages of POM degradation in marine and lake environments (Meckler et al. 2004, Schubert et al. 2005, Bechtel \& Schubert 2009, Carstens et al. 2012).

Organic particles have been identified as hot spots of microbial activity. Particle-associated bacteria have been shown to hydrolyze more organic matter than they take up and, thus, they are considered to provide significant growth substrates for free-living bacteria in the surrounding waters (Smith et al. 1992, Grossart \& Simon 1998). As specific bacterial guilds are specialized in the degradation of certain substrates (Peter et al. 2011, Salcher et al. 2012), it would be expected that organic matter quality and composition have a strong impact on the structure of BCs. Shifts in freshwater BCC related to organic matter quality changes in time or between water bodies have been shown previously (Crump et al. 2003, Roiha et al. 2011). Recently published studies on diverse temperate lakes have further revealed distinct dynamics of particle-associated $(>5 \mu \mathrm{m})$ and free-living $(>0.2,<5 \mu \mathrm{m}) \mathrm{BCs}$ in relation to biotic and abiotic factors (Allgaier et al. 2007, Parveen et al. 2011, Rösel et al. 2012). However, at present our understanding of the interactions between organic matter and $\mathrm{BCC}$ in the particle-associated and freeliving fractions during the sedimentation process in deeper lakes is very limited.

In the present study, we aimed to analyze the vertical compositional changes of $\mathrm{BCs}$ in relation to compositional shifts and quality of POM in the water column of 2 contrasting lakes. The particle-associated and the free-living $\mathrm{BCs}$ were separated via serial filtration. The vertical compositional changes of both BCs were analyzed by automated ribosomal intergenic spacer analysis (ARISA) and linked to bulk parameters such as total organic carbon (TOC), oxygen $\left(\mathrm{O}_{2}\right), \mathrm{pH}$, temperature $(\mathrm{T})$, and to various parameters indicating POM degradation state and composition.

We hypothesized that shifts in the composition and degradation state of POM in a lake water column are accompanied by shifts in bacterial abundance and BCC. Further, we hypothesized that distinct environmental parameters shape the BCs in an oligotrophic, fully oxic water column compared to a eutrophic, partially anoxic water column. Finally, different structure-function relationships were expected for particle-associated versus free-living BCs.

To test these hypotheses, we applied redundancy analysis (RDA) and partial RDA in combination with forward selection to identify the environmental parameters with the strongest impact on the BCC dynamics. Variation partitioning was performed to test the significance of the individual contribution of each variable. Whereas amino-compound based degradation indices performed less well as predictors for the structure of the particle-associated BCs, the CI appeared to be a good explanatory parameter for the total bacterial cell abundance and the vertical 
compositional shifts of the free-living BCs. In comparison to the free-living BCs, the particle-associated BCs of both lakes appeared to be more determined by the sampling date and $\mathrm{pH}$.

\section{MATERIALS AND METHODS}

\section{Sampling site and sampling}

The characteristics of the 2 lakes studied in Switzerland are described in detail elsewhere (Köllner et al. 2012). Briefly, Lake Brienz (LB) is an oligotrophic, fully oxic lake with a maximum depth of 259 $m$. The South Basin of eutrophic Lake Zug (LZ) is meromictic and anoxic below $130 \mathrm{~m}$. It has a maximum depth of $200 \mathrm{~m}$.

The sampling procedure is also described in detail elsewhere (Köllner et al. 2012). Briefly, LB was sampled in mid-May and mid-September 2009, and the South Basin of LZ was sampled at the end of March and end of October 2009. Based on $\mathrm{T}$ and $\mathrm{O}_{2}$ profiles, water from LB was sampled at 5, 10, 20, 30, 40, 70, $100,150,200$, and $240 \mathrm{~m}$ depth and from LZ at 5, 10, $15,25,60,80,100,130,170$, and $190 \mathrm{~m}$. For both lakes, the samples were collected over the deepest point of the basin. For AA, AS, and CI analyses (described below), POM from the same depths was sampled onto 2 stacked pre-combusted glass fiber filters (nominal pore size $0.7 \mu \mathrm{m}, 142 \mathrm{~mm}$ diameter; Whatman) with in situ pumps (McLane Research Laboratories) until filters were clogged.

\section{Water chemistry}

Concentrations of TOC and total nitrogen (TN) were taken from Köllner et al. (2012). Total phosphorus (TP) concentrations were determined photometrically in unfiltered water samples with the molybdenum blue method of Vogler (1965). Alkalinity was analyzed by titration with $0.1 \mathrm{~N} \mathrm{HCl}$ to $\mathrm{pH} 4.3$ with an automatic titration system (716 DMS Titrino, Metrohm). For determination of chloride $\left(\mathrm{Cl}^{-}\right)$, nitrate $\left(\mathrm{NO}_{3}{ }^{-}\right)$, and sulfate $\left(\mathrm{SO}_{4}{ }^{2-}\right)$ concentrations, aliquots were filtered through cellulose acetate filters with $0.45 \mu \mathrm{m}$ pore size (Whatman). Analysis was performed using a Metrohm ion chromatograph (3.2 mM $\mathrm{Na}_{2} \mathrm{CO}_{3} / 1.0 \mathrm{mM} \mathrm{NaHCO}$ buffered solution, $0.7 \mathrm{ml}$ $\min ^{-1}$ flow rate) and a Metrohm Anion Metrosep A Supp 5 column. Concentrations of the base cations calcium $\left(\mathrm{Ca}^{2+}\right)$, magnesium $\left(\mathrm{Mg}^{2+}\right)$, and sodium $\left(\mathrm{Na}^{+}\right)$ were also measured with a Metrohm ion chromato- graph (1.7 mM nitric acid/0.7 mM dipicolinic acid

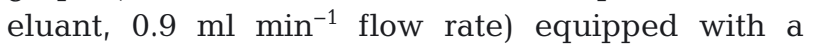
Metrohm Metrosep C4 column.

\section{Particulate amino acids}

The concentrations of 14 particulate AAs, alanine (Ala), glycine (Gly), threonine (Thr), serine (Ser), valine (Val), leucine (Leu), isoleucine (Ile), proline (Pro), aspartic acid (Asp), methione (Met), glutamic acid (Glu), phenlyalanine (Phe), tyrosine (Tyr), and lysine (Lys), were measured. For this purpose, one quarter of each $0.7 \mu \mathrm{m}$ filter was hydrolyzed with $6 \mathrm{~mol} \mathrm{l}^{-1} \mathrm{HCl}$ for $20 \mathrm{~h}$ at $110^{\circ} \mathrm{C}$ under $\mathrm{N}_{2}$. Prior to hydrolysis, L-norleucine (Sigma) was added as an internal standard. The samples were then processed as described previously (Carstens \& Schubert 2012) using a GC system with a flame ionization detector (Shimadzu Scientific Instruments) and a 5MS/NP column (20 m, $0.25 \mathrm{~mm}$ inner diameter, and $0.25 \mu \mathrm{m}$ film thickness, GL Sciences).

\section{Degradation index, particulate amino sugars, and $\mathbf{C I}$}

The data for particulate ASs, the degradation index (DI), and the CI, which is based on the degradation state of chlorins, have been published previously and methods of analysis were described in detail elsewhere (Carstens \& Schubert 2012, Carstens et al. 2012). The DI is an amino-acid based index that was developed by Dauwe \& Middelburg (1998) and Dauwe et al. (1999) and was applied with minor modifications as described by Carstens \& Schubert (2012).

\section{Total bacterial cell counts}

The data for total number of bacterial cells were published previously (Carstens et al. 2012). Analysis was performed with a CyFlow Space instrument (Partec) as described elsewhere (Carstens et al. 2012). Briefly, water was sampled using sterile $50 \mathrm{ml}$ centrifuge tubes (Greiner Bio-One). Bacterial cells were fixed by adding freshly prepared $20 \%$ paraformaldehyde (Sigma) to a final concentration of $2 \%$. Of the fixed sample, $1 \mathrm{ml}$ was mixed with $10 \mu \mathrm{m} \mathrm{m} \mathrm{m}^{-1}$ SYBR Green I (1:100 dilution in dimethyl sulfoxide; Molecular Probes) and incubated in the dark for $15 \mathrm{~min}$ at room temperature to stain bacterial cells. 


\section{DNA extraction}

To separate the free-living and the particle-associated BCs, $\sim 51$ of water from each sampled depth were filtered through a $5.0 \mu \mathrm{m}$ isopore membrane filter (Millipore) and a $0.2 \mu \mathrm{m}$ polycarbonate filter (Whatman), each $142 \mathrm{~mm}$ in diameter, connected in series and processed for DNA extraction as described previously (Köllner et al. 2012).

The quality of DNA extracts was checked using agarose gel (1\%) electrophoresis. Extracted DNA was quantified by fluorescence spectroscopy using the Quant-iT PicoGreen dsDNA Assay Kit (Molecular Probes) and a Synergy HT microplate reader (BioTek Instruments). The DNA extraction yields per filter and water depth are available in Table S1 in the Supplement at www.int-res.com/articles/suppl/a069 p081_supp.pdf).

\section{Amplification of ribosomal intergenic spacer fragments}

Intergenic ribosomal spacer fragments were amplified from $10 \mathrm{ng}$ of extracted DNA as described previously (Fisher \& Triplett 1999, Yannarell et al. 2003). One $\mu$ l of ARISA-PCR product was added to a master mix containing $0.5 \mu \mathrm{l}$ of internal size standard LIZ 1200 (GeneScan, Applied Biosystems) and $9 \mu \mathrm{l}$ of deionized Hi-Di formamide (Applied Biosystems). After denaturation for $3 \mathrm{~min}$ at $95^{\circ} \mathrm{C}$, the samples were immediately placed on ice. Fragment size analysis was performed on an ABI 3130xl capillary sequencer using a $50 \mathrm{~cm}$, 16-capillary array and POP-7 polymer (Applied Biosystems). Fragment analysis was performed with GeneMapper software v 4.0 (Applied Biosystems). Only peaks with sizes between 350 and $1250 \mathrm{bp}$ and a minimum peak height of 150 fluorescence units were considered for analysis. The capillary electrophoresis was performed with triplicate ARISAPCR samples of the particle-associated BCs and quadruplicate ARISA-PCR samples of the free-living BCs. Only peaks with a consistent presence in 2 (particleassociated) to 3 (free-living) ARISA-PCR replicates were included in further analyses.

\section{Binning}

Binning of ARISA fragments was performed as described previously (Ramette 2009). In order to determine the best window size (WS), the automatic R (R Development Core Team 2009) binning script (avail- able online at www.mpi-bremen.de/en/Software_2. $\mathrm{html}$ ) was applied to replicates of at least 1 representative sample (highest number of ARISA fragments) for each sampling and both bacterial size fractions. The correlation between the replicates and the respective number of operational taxonomic units (OTUs) for a series of WS values $(0.5,1,1.5,2,3,4$, and $5 \mathrm{bp})$ and a shift value (Sh) of 0.1 bp was calculated. As a compromise between high resolution and high similarity between sample replicates, a WS of $3 \mathrm{bp}$ was used for the OTU binning algorithm for ARISA profiles from both free-living and particle-associated BCs.

\section{Statistical analyses}

All statistical analyses were performed using the statistical software R version 2.14.0 with packages VEGAN (Oksanen et al. 2011) and BIODIVERSITY R (Kindt \& Coe 2005). For cluster analysis, average linkage of hierarchical cluster analysis was used with the distance among communities calculated as BrayCurtis distances. Prior to cluster analysis and RDA, the ARISA-OTU data were Hellinger-transformed (Legendre \& Gallagher 2001, Ramette 2007). The environmental data used for principal component analysis (PCA) and RDA were z-standardized to offset different units and scales, and their corresponding abbreviations are given in Table 1. For linear model analysis, environmental data that were not normally distributed (Shapiro-Wilk test, p > 0.001) were log-transformed. Variables that were not normally distributed even after transformation were not included in the analysis.

RDA was performed as described by Borcard et al. (2011b). For variable reduction and in order to create an efficient model from the most significant explanatory variables, forward selection of constraints using the forward.sel function of the $\mathrm{R}$ package packfor (Dray et al. 2009) and VEGAN'S ordistep function were applied according to Borcard et al. (2011a). Two variable selection procedures were applied to test whether both select for the same most significant explanatory variables. The RDA model was tested by performing partial RDA, with depth as the conditional variable, and variation partitioning (Legendre \& Gallagher 2001, Peres-Neto et al. 2006) to test the significance of the contribution of each individual variable.

In order to investigate whether there are significant differences in the composition of free-living and particle-associated $\mathrm{BCs}$, a multiple response permutation procedure (MRPP) was computed using the $\mathrm{R}$ package VEGAN. 
Table 1. Environmental variables used for ordination analyses (principal component and redundancy analyses) and their corresponding abbreviations

\begin{tabular}{|c|c|}
\hline Variable & Abbreviation \\
\hline Total organic carbon ${ }^{\mathrm{a}}$ & TOC \\
\hline Total nitrogen $^{\mathrm{a}}$ & $\mathrm{TN}$ \\
\hline $\begin{array}{l}\text { Ratio between total organic carbon } \\
\text { and total nitrogen }\end{array}$ & $\mathrm{C}: \mathrm{N}$ \\
\hline Total phosphorus ${ }^{\mathrm{a}}$ & TP \\
\hline Nitrate $^{\mathrm{a}}$ & $\mathrm{NO}_{3}^{-}$ \\
\hline Sulfate $^{a}$ & $\mathrm{SO}_{4}{ }^{2-}$ \\
\hline Calcium $^{\mathrm{a}}$ & $\mathrm{Ca}^{2+}$ \\
\hline Sodium & $\mathrm{Na}^{+}$ \\
\hline Chloride & $\mathrm{Cl}^{-}$ \\
\hline Magnesium & $\mathrm{Mg}^{2+}$ \\
\hline Alkalinity $^{\mathrm{a}}$ & - \\
\hline Oxygen $^{\mathrm{a}}$ & $\mathrm{O}_{2}$ \\
\hline $\mathrm{pH}^{\mathrm{a}}$ & - \\
\hline Temperature $^{\mathrm{a}}$ & $\mathrm{T}$ \\
\hline Particulate glucosamine ${ }^{\mathrm{a}}$ & GlcN \\
\hline Particulate mannosamine $^{\mathrm{a}}$ & ManN \\
\hline Particulate galactosamine $^{\mathrm{a}}$ & GalN \\
\hline Particulate muramic acid ${ }^{\mathrm{a}}$ & MurA \\
\hline Particulate glutamic acid ${ }^{\mathrm{a}, \mathrm{b}}$ & Glu \\
\hline $\begin{array}{l}\text { Ratio between particulate glucosamine } \\
\text { and particulate galactosamine }{ }^{\mathrm{a}}\end{array}$ & GlcN:GalN \\
\hline $\begin{array}{l}\text { Sum of particulate amino acid concentra- } \\
\text { tions divided by the sum of particulate } \\
\text { amino sugar concentrations }^{\text {a }}\end{array}$ & AAs:ASs \\
\hline Chlorin index ${ }^{\mathrm{a}}$ & CI \\
\hline Degradation index & DI \\
\hline \multicolumn{2}{|c|}{ 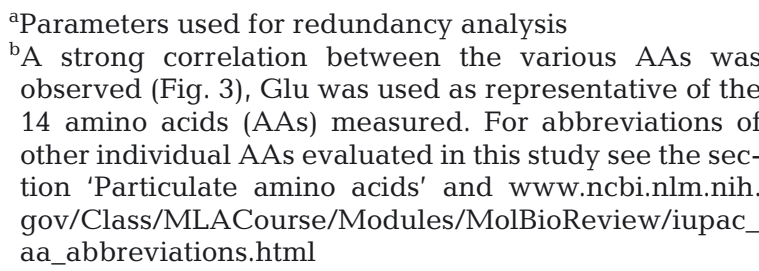 } \\
\hline
\end{tabular}

The total bacterial cell number and the number of ARISA-OTUs each were analyzed as a function of multiple factors (lake, sampling date, depth) by a linear model approach using ANOVA in R. In order to find the best subset of environmental variables for predicting total bacterial cell counts and OTU number, the stepAIC() function from the R package MASS (Venables \& Ripley 2002) and ANOVA were used.

\section{RESULTS}

\section{Physico-chemical and biological characterization on the sampling dates}

The physico-chemical and biological characterization of the lakes, which were sampled in spring and fall 2009, are described in detail elsewhere (Carstens et al. 2012, Köllner et al. 2012) and are available in Table S2 in the Supplement). In short, at both sampling times, the water column of LB was fully oxic. For LZ, anoxic conditions were measured below $130 \mathrm{~m}\left(\mathrm{O}_{2}<0.1 \mathrm{mg} \mathrm{l}^{-1}\right)$. LB was thermally stratified on both sampling dates. In May, $\mathrm{T}$ was constantly $5^{\circ} \mathrm{C}$ below a water depth of $70 \mathrm{~m}$ (hypolimnion), while in September the hypolimnion ranged from 40 to $240 \mathrm{~m}$ water depth. The maximum $\mathrm{T}$ of $14^{\circ} \mathrm{C}$ was measured in September at $5 \mathrm{~m}$ water depth in LB. For LZ, the maximum $\mathrm{T}$ of $13^{\circ} \mathrm{C}$ was measured in the surface waters (5 and $10 \mathrm{~m}$ water samples) in October, when a late fall phytoplankton bloom was observed. In March, the water column of LZ was not thermally stratified, with $\mathrm{T}$ values below $5^{\circ} \mathrm{C}$ throughout the water column. For both lakes, the $\mathrm{pH}$ was higher in spring than in fall and ranged from 7.2 (LZ October, $190 \mathrm{~m}$ ) to 8.5 (LZ March, $15 \mathrm{~m})$.

\section{Degradation indices based on particulate amino acids and amino sugars}

The vertical shifts of particulate AS concentrations were published elsewhere (Carstens et al. 2012) and are available in Table S2. Particulate AA concentrations are shown in Table S3. For both lakes and sampling dates, the particulate AA concentrations decreased with water depth with a slight increase just above the sediments. The most abundant AAs were the acidic AAs Glu (up to $473 \mathrm{nmol}^{-1}$ ) and Asp (up to $393 \mathrm{nmol} \mathrm{l}^{-1}$ ) and the neutral AAs Leu (up to $309 \mathrm{nmol}$ $\mathrm{l}^{-1}$ ), Ala (up to $287 \mathrm{nmol}^{-1}$ ), and Gly (up to $239 \mathrm{nmol}$ $\mathrm{l}^{-1}$ ). Maximum AA concentrations were measured for the $5 \mathrm{~m}$ water depth of LZ sampled in October. The AA concentrations of LZ were 2- to 10-fold higher than for LB. Minimum concentrations $\left(<1 \mathrm{nmol} \mathrm{l}^{-1}\right)$ were measured for the sulfuric AA Met and the aromatic AA Tyr for both lakes and sampling dates.

The DI, which is based on the variation of mole percentages of particulate AAs, and the AA:AS ratios are shown in Fig. S1 in the Supplement at www.intres.com/articles/suppl/a069p081_supp.pdf in the context of the vertical profiles of GlcN:GalN and CI, which were already published elsewhere (Carstens et al. 2012). As Ala could not be detected for 10, 150, and $240 \mathrm{~m}$ water depth of LB in September, the DI was not calculated for these samples. In May, the DI showed a trend towards lower values with depth, which would indicate a degradation of sedimenting material (Dauwe et al. 1999). For LZ, the DI showed a drop in the water depth where the water column got anoxic and increased again for deeper water layers. 


\section{Total bacterial cell counts}

The highest total bacterial cell counts were detected in the epilimnion of LZ (Carstens et al. 2012). Linear model analysis using ANOVA was applied to investigate the effect of multiple factors (lake, sampling date, depth) on the total bacterial cell abundance. Each of the 3 factors had a significant effect on the total bacterial cell abundance (lake: $p<0.001$, depth: $\mathrm{p}<0.001$, sampling date: $\mathrm{p}<0.05$ ), but not in an interactive manner. According to the results of the Shapiro-Wilk test $(p>0.001)$ linear model analysis (ANOVA) in combination with stepwise selection was performed with the following variables: $\mathrm{TN}, \mathrm{pH}$, DI, $\log (\mathrm{TP}), \log$-transformed ASs, log-transformed AAs, $\log (\mathrm{GlcN}$ :GalN), $\log (\mathrm{CI}), \log (\mathrm{C}: \mathrm{N})$ and $\log (\mathrm{AAs}$ : ASs). Instead of using all AAs in the linear model analysis, $\log (\mathrm{Glu})$ was used to represent all AAs. The final model for the total bacterial cell counts was $\log ($ cells $) \sim \log (\mathrm{GlcN})+\log (\mathrm{CI})+\log (\mathrm{AAs}: \mathrm{ASs})$.

\section{OTU number and community structure of particle-associated and free-living bacteria}

The number of OTUs was defined by the number of detected ARISA fragments. Per water depth, it ranged from $48 \pm 1$ (mean \pm SD) to $75 \pm 2$ and from $21 \pm 1$ to $69 \pm 1$ for the free-living and the particleassociated BCs, respectively (Fig. 1). When performing a pairwise comparison per sampling depth (separately for each sampling date and lake), the OTU number of the free-living BCs was significantly higher compared to the particle-associated BCs (pairwise $t$-test, $\alpha=0.05, \mathrm{p}<0.0001$ ) with the exception of LZ in October ( $t$-test, $\alpha=$ $0.05, p=0.08$ ). Comparing lakes, the number of OTUs was not significantly different ( $t$-test, $\alpha=0.05$ : free-living, $\mathrm{p}=0.80 ;$ particle-associated, $\mathrm{p}=0.60$ ).

As for the total bacterial cell number, the effect of multiple factors (lake, sampling date, depth) on the number of ARISA-OTUs was investigated. For the OTU number of the particle-associated BCs, the most significant effect was the lake-depth interaction $(\mathrm{p}<$ $0.001)$ and sampling date $(\mathrm{p}<0.001)$. The effect of the lake-sampling date interaction was also significant $(\mathrm{p}<$ 0.05). Stepwise selection of environ- mental constraints as described for the total bacterial cell number resulted in the following final model: OTUs $\sim \mathrm{TN}+\mathrm{pH}+\mathrm{DI}+\log (\mathrm{TP})+\log (\mathrm{GlcN})+$ $\log (\mathrm{Glu})+\log (\mathrm{C}: \mathrm{N})+\log (\mathrm{AAs}: \mathrm{ASs})$.

For the OTU number of the free-living $\mathrm{BCs}$, the most significant effect was the lake-sampling date interaction $(p<0.001)$, followed by the lake-depth interaction $(p<0.01)$, the sampling date-depth interaction $(\mathrm{p}<0.05)$, season $(\mathrm{p}<0.05)$ and depth $(\mathrm{p}<$ 0.05). Linear model analysis (ANOVA) and stepwise selection of environmental contraints resulted in the following final model for the vertical shifts of the OTU number of the free-living BCs: OTUs $\sim$ DI $+\log (\mathrm{TP})+$ $\log (\mathrm{GlcN})+\log (\mathrm{GalN})+\log (\mathrm{MurA})+\log (\mathrm{Glu})+$ $\log (\mathrm{GlcN}: \mathrm{GalN})+\log (\mathrm{CI})+\log (\mathrm{C}: \mathrm{N})+\log (\mathrm{AAs}: \mathrm{ASs})$.

The cluster analysis of the ARISA profiles of particle-associated BCs separated LB and LZ into distinct clusters (Fig. 2A). Within the LZ cluster, the anoxic water samples were separated from the oxic water samples. The subclustering of the oxic water samples of both lakes was determined by the sampling date. In comparison, for the free-living BCs the 2 main clusters were formed by the anoxic water layers of LZ and the oxic water layers of both lakes (Fig. 2B). In the oxic water cluster of LZ, the $25 \mathrm{~m}$ water depth sampled in October was distinct from the epilimnion and grouped with the water depths sampled along the oxycline of LZ. Within the LB cluster, the hypolimnion was distinct from the epilimnion. The LB

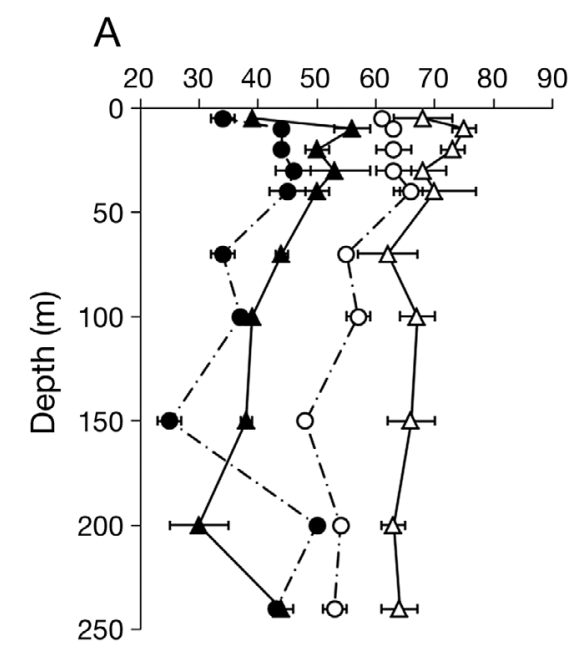

Fig. 1. Number of ARISA-operational taxonomic units (OTUs) analyzed for the free-living bacterial communities (BCs; open symbols) and particle-associated BCs (filled symbols) of (A) Lake Brienz sampled in May and September 2009 and (B) Lake Zug sampled in March and October 2009. Error bars indicate standard deviations of triplicate or quadruplicate ARISA fragment analysis of particle-associated or free-living BCs, respectively 


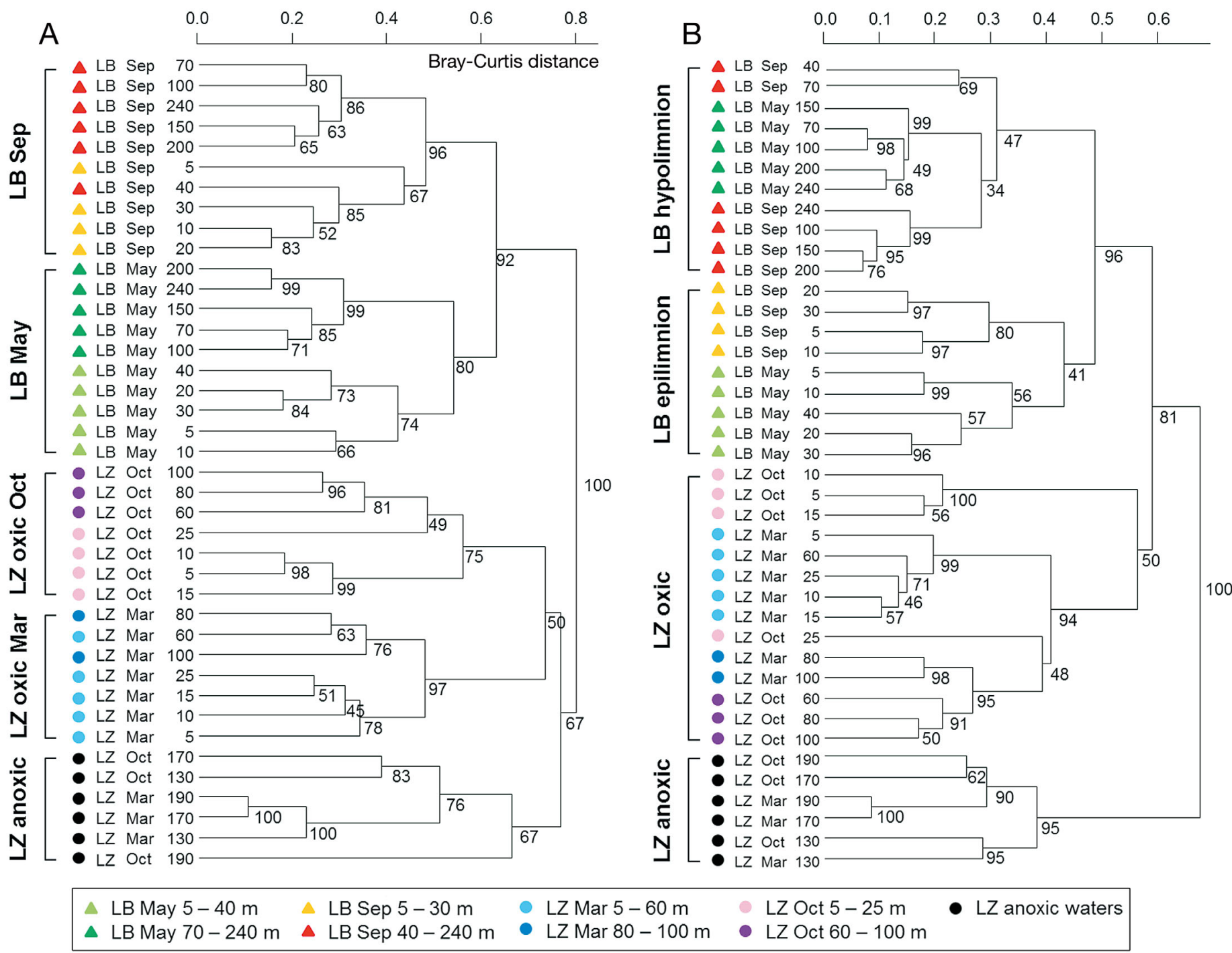

Fig. 2. Hellinger-transformed ARISA data of (A) particle-associated and (B) free-living bacterial communities (BCs). Water of Lake Brienz (LB, triangles) was sampled in May and September 2009 and of Lake Zug (LZ, circles) in March and October 2009 based on temperature and $\mathrm{O}_{2}$ profiles (Köllner et al. 2012). Symbol colors indicate grouping by season and water layer, i.e. for LB epi- and hypolimnion and for LZ, oxic, oxycline, and anoxic water layers. Hierarchical cluster analysis was performed using average linkage, and Bray-Curtis distances were calculated from ARISA peak abundance. Bootstrap values in $\%$ from 1000 replicates are given at branch nodes

hypolimnion cluster included the 70 to $240 \mathrm{~m}$ water depth of the spring sampling and the 40 to $240 \mathrm{~m}$ water depth of the fall sampling. This finding is in good agreement with recorded conductivity-temperature-depth profiles (Köllner et al. 2012).

The MRPP test showed that for both lakes the particle-associated BCs were significantly different from the free-living $\mathrm{BCs}$ (mean distance within groups $=0.58$, mean distance between groups $=$ 0.79 ). The BCs appeared more similar within the free-living fraction (LB: $\delta=0.41, \mathrm{LZ}: \delta=0.57$ ) than within the particle-associated fraction (LB: $\delta=0.63$, LZ: $\delta=0.71$ ). The significance of the delta scores based on 999 permutations was 0.001 .

\section{Explanatory variables with the strongest influence on between- and within-lake variability of the bacterial community structure}

In total, we assembled and evaluated 36 variables (listed in Table 1), which included concentrations of 
TOC, TN, TP, ions, alkalinity, $\mathrm{pH}, \mathrm{T}, \mathrm{O}_{2}$, concentrations of particulate ASs and AAs, ratios thereof, the $\mathrm{DI}$, and the $\mathrm{CI}$ to determine their influence on the $\mathrm{BC}$ structures.

As a first step, PCA was performed on this initial set of environmental variables. The circle of equilibrium contribution identified $\mathrm{TP}, \mathrm{TOC}$, ions, alkalinity, $\mathrm{O}_{2}$, and $\mathrm{T}$ as the variables contributing most to the ordination graph (Fig. 3). The 2 lakes were clearly separated, which reflects the high concentrations of ions, TOC, and TP of LZ and the high $\mathrm{SO}_{4}^{2-}$ and $\mathrm{O}_{2}$ concentrations of LB. The 5 to $25 \mathrm{~m}$ and the 5 to $15 \mathrm{~m}$ water layers of LZ sampled in spring and fall, respectively, segregated from the main LZ cluster (Fig. 3). The 5 and $10 \mathrm{~m}$ water samples from fall plotted outside of the equilibrium circle. This is mainly due to the high AS and AA concentrations in the surface waters of LZ. Fig. 3 further illustrates the high degree of overall correlation between the various amino compounds measured, as well as their distinctness from bulk parameters such as TN and TOC.

Based on the observed collinearities between various AAs and between various ions measured, the RDA was based on a reduced set of 19 explanatory variables, TOC, TN, $\mathrm{TP}, \mathrm{NO}_{3}{ }^{-}, \mathrm{SO}_{4}^{2-}, \mathrm{Ca}^{2+}$, alkalinity,

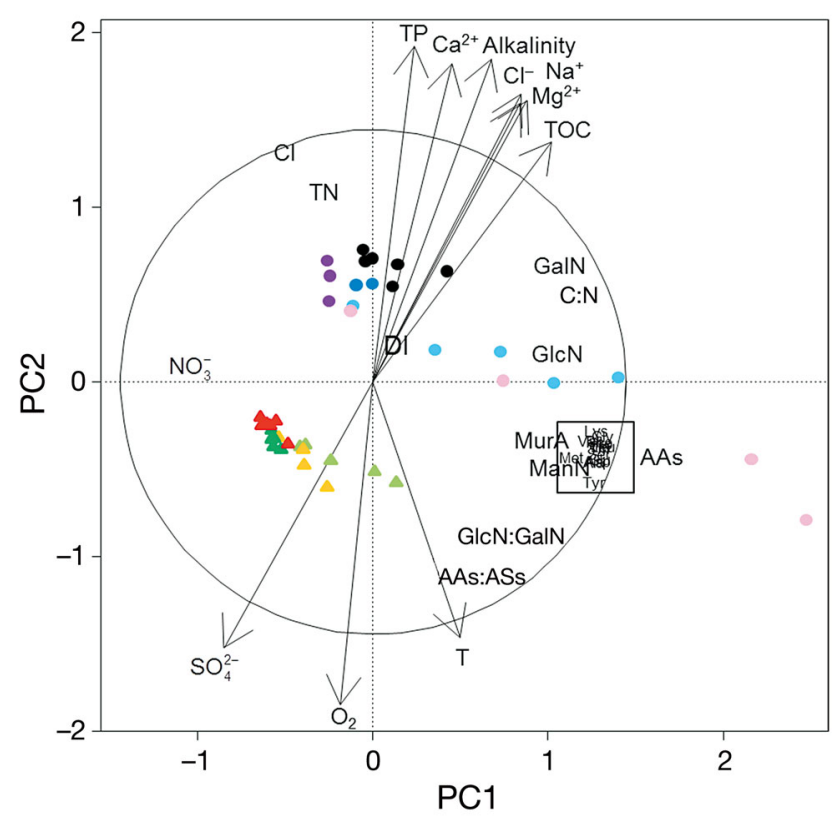

Fig. 3. Principal component analysis of 36 environmental variables and circle of equilibrium contribution which highlights the variables contributing significantly to the ordination, i.e. variables that have vectors outside of the equilibrium circle. The first 2 axes represent $76.8 \%$ of the variance. For abbreviations used see Table 1. Water samples from Lake Brienz are symbolized by triangles and Lake Zug by circles. For color code see Fig. 2
$\mathrm{O}_{2}, \mathrm{pH}, \mathrm{T}, \mathrm{GlcN}, \mathrm{ManN}$, GalN, MurA, Glu (as representative for all AAs), GlcN:GalN, C:N, AAs:ASs, and the CI.

As the anoxic communities of LZ followed a very different dynamic (Fig. 2), particular trends between the different BCs of the 2 lakes may be obscured in the RDA. In this section, we mainly describe the results for the RDA of the oxic water samples. The RDAs including the anoxic water samples are shown in Fig. S2 in the Supplement.

Given the considerable collinearities between the various environmental variables, variable selection was applied. The forward.sel and the ordistep functions both selected the same set of 10 explanatory variables for the RDA of the particle-associated $\mathrm{BC}$ data (Fig. 4A). pH was strongly correlated with axis 2, which indicates its influence on the sampling date related variation of the particle-associated BCC. The separation of the particle-associated BCs of LZ and LB along the first axis and of the sampling dates along the second axis was preserved in the RDA also comprising the anoxic water samples (see Fig. S2A in the Supplement). Variation partitioning showed that all variables in the RDA model contributed significantly to the model, except for TOC (see Table S4 in the Supplement). The highest individual contributions were attributed to $\mathrm{T}, \mathrm{C}: \mathrm{N}$, and CI. Partial RDA with depth as the conditional variable (Fig. S3A in the Supplement) slightly emphasizes the effect of $\mathrm{T}$.

For the free-living BCs, the same explanatory variables as for the particle-associated BCs except for $\mathrm{pH}$ were selected (Fig. 4B). The parsimonious RDA indicated that within-lake variability was best explained by the variables $\mathrm{T}, \mathrm{NO}_{3}{ }^{-}$, and CI. Partial RDA with depth as the conditional variable (Fig. S3B in the Supplement) reduces the apparent effect of the highly depth-correlated CI. Variation partitioning showed that all variables in the RDA model contributed significantly to the model (see Table S4 in the Supplement). The highest individual contributions were attributed to $\mathrm{T}, \mathrm{C}: \mathrm{N}$, and $\mathrm{SO}_{4}^{2-}$.

Reflecting the main differences between the 2 lakes (Fig. 3), the BCs of LB were always correlated to high $\mathrm{SO}_{4}^{2-}, \mathrm{O}_{2}$, and $\mathrm{NO}_{3}{ }^{-}$concentrations, and the BCs of LZ were always correlated to high alkalinity, C:N, TOC, and TP concentrations (Figs. 4 \& S2).

\section{DISCUSSION}

We investigated the influence of concentrations and quality of particulate organic compounds in 

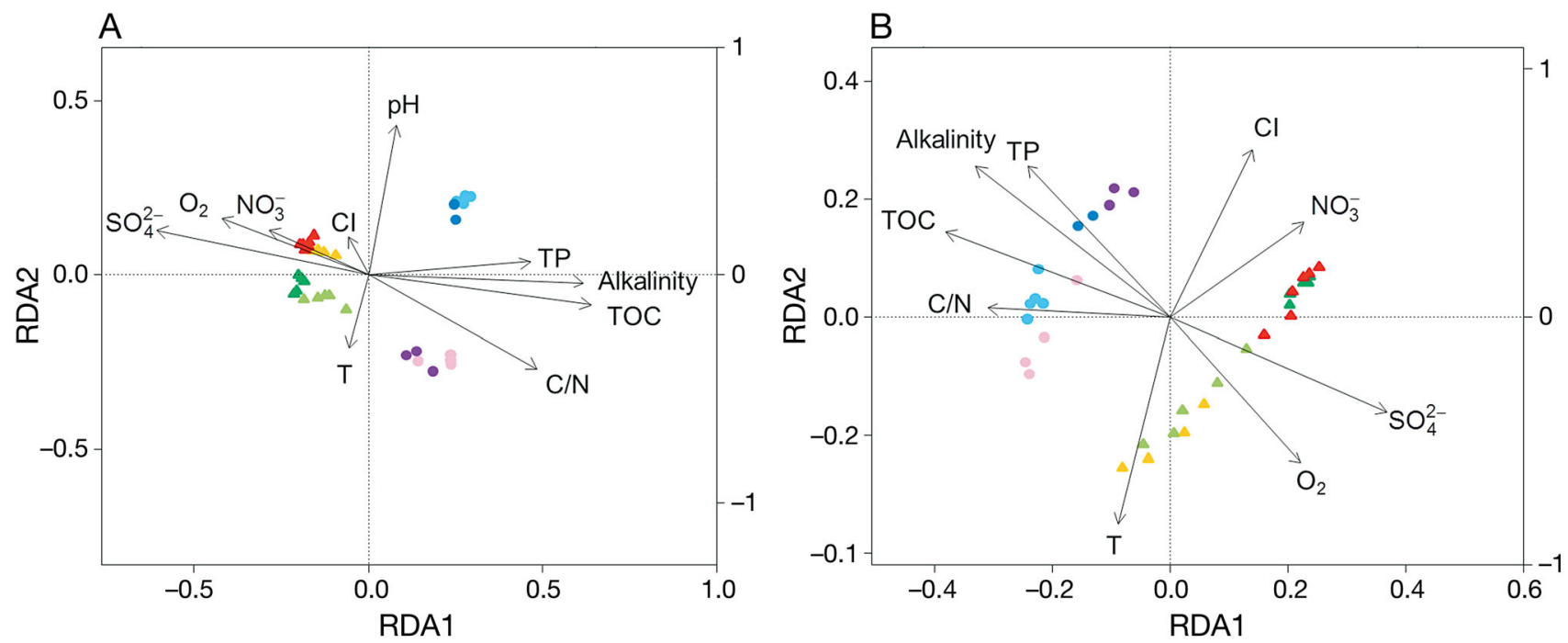

Fig. 4. Redundancy analysis (RDA) triplots of Hellinger-transformed ARISA data of (A) particle-associated and (B) free-living bacterial communities (BCs) and constraining environmental variables. Only oxic water samples were plotted. For the RDA of the particle-associated BCs, the first 2 canonical axes explain $37.8 \%$ of the total variance of the data. For the RDA of the free-living BCs, the first 2 canonical axes explain $40.5 \%$ of the total variance of the data. Water samples from Lake Brienz are symbolized by triangles and Lake Zug by circles. For color code see Fig. 2

addition to bulk physico-chemical parameters on the vertical structure of BCs in the water columns of 2 contrasting lakes. Due to the strong depth-related gradients by which a lake water column is characterized and many of which are autocorrelated, care has to be taken in identifying the environmental variables that drive vertical bacterial dynamics. In the present study, we used a stepwise reduction of variable complexity aided by forward selection to extract the set of environmental variables with the strongest influence on the BCC dynamics. We analyzed both full and partial datasets, e.g. separate analysis of the oxic/anoxic water body, to confirm consistency of trends. Further, we applied partial RDA with water depth as the conditional variable and variation partitioning to test the significance of the individual contribution of each environmental variable. Finally, we evaluated the probable causality of the considered variables.

The BCs in the 2 contrasting lakes selected for this study were clearly separated (Fig. 2), which was best explained by the distinct concentrations of TOC, TP, $\mathrm{SO}_{4}, \mathrm{NO}_{3}, \mathrm{O}_{2}$, and alkalinity (Fig. 4), variables generally related to the different trophic statuses of the 2 lakes. Gradients of TOC together with primary productivity were suggested previously as fundamental determinants of freshwater BCC dynamics (Yannarell \& Triplett 2004, Allgaier \& Grossart 2006), as these parameters integrate over the sources of energy used by bacteria for growth.
As expected, the anoxic hypolimnion of LZ harbored a unique BC. As bacteria in this region will have to rely on anaerobic respiration and fermentation, it is to be expected that only few organisms with highly flexible metabolism will thrive both above and below the oxycline.

The strong effect of $\mathrm{T}$ on both the composition of the particle-associated and the free-living BCs probably reflects the physical and biological structure of the lake, rather than it being a direct influence by itself: warm and light zone of primary production in the surface waters versus dark and cold conditions in the hypolimnion, the zone of detrital matter turnover. $\mathrm{T}$ has previously been demonstrated as a significant variable reflecting the variance between epilimnion and hypolimnion BCs (Shade et al. 2008).

In comparison to the free-living $\mathrm{BCs}$, the particleassociated BCs were more variable in their composition and stronger influenced by the sampling date and $\mathrm{pH}$. $\mathrm{pH}$ has previously been identified as an important driver of biogeochemical transformations and as a cause of shifts in lake BCC (Lindström 2000, Yannarell \& Triplett 2005). pH is also the most important driver of soil BCC (Fierer \& Jackson 2006).

The stronger impact of the sampling date on particle-associated BCs compared to free-living BCs is in good agreement with recently published studies on the dynamics of these bacterial groups in lakes located in Germany (Rösel \& Grossart 2012, Rösel et al. 2012). The pronounced seasonal dynamics of 
particle-associated BCs were linked to their tighter coupling to phyto- and zooplankton, as particle-associated bacterial species strongly correlated to algal species and zooplankton biomass were found (Rösel et al. 2012). In the lakes presented here, the zooplankton and phytoplankton of LZ differed substantially between the spring and the fall sampling, in both biomass and composition (Köllner et al. 2012), while it remained more constant in LB. This may be reflected in the stronger separation of particle-associated BCs in LZ by the sampling date (Fig. 4A). The influence of seasonal phytoplankton successions on the BCC was shown previously, as different algal species are sources for different types of substrates utilized by the bacterioplankton (Lindström 2001, Crump et al. 2003, Eiler \& Bertilsson 2007, Šimek et al. 2011). The $>5 \mu \mathrm{m}$ fraction probably also comprises the preferred food particle size of crustaceans (Langenheder \& Jürgens 2001). Therefore, BCs in the $>5 \mu \mathrm{m}$ fractions are probably more closely associated with the seasonal dynamics of these biota.

The abundance of specific particulate amino compounds and the derived degradation indices performed less well as predictors for BCC dynamics in the lake water columns. The GlcN:GalN and the AAs:ASs patterns (Fig. S1 in the Supplement) indicate that within the water column of both lakes, the degradation dynamics of particulate amino compounds were mainly restricted to the surface waters. However, linear model results assigned particulate amino compounds as significant determinants for the number of ARISA-OTUs (Fig. 1) of both the particle-associated and the free-living $\mathrm{BCs}$, and for the total bacterial abundance. Particulate amino compounds are not only significant growth substrates for particle-associated BCs, which accomplish the hydrolysis of POM, but also for the free-living bacteria profiting from the hydrolysis products released as DOM in the surrounding water (Grossart \& Simon 1998, Beier \& Bertilsson 2011, Salcher et al. 2012). DOM is the major source of carbon and energy for aquatic microbes (Azam et al. 1983). However, in oligotrophic LB, concentrations of dissolved amino compounds were below the limit of detection. For LZ, for which concentrations of dissolved ASs could be measured, the degradation indices AAs:ASs, CI, and C:N correlated significantly ( $\mathrm{p}<0.001, \mathrm{n}=20$, data not shown) with the concentrations of dissolved GlcN and GalN and DOC, which indicates the significance of the degradation of particulate amino compounds and primary produced POM for the release of important growth substrates for aquatic biota.
The chlorin-based degradation index CI was found to be associated with the within-lake variation of the free-living BCC (Figs. 4B \& S2B in the Supplement). This was the case in both lakes despite the contrasting nutrient and redox conditions. We do, however, note that CI is highly correlated with water depth in both systems, and consequently, its explanatory power is reduced when the effect of the water depth is eliminated (partial RDA, Fig. S3B in the Supplement). For both lakes and samplings, the CI increased throughout the water column towards the lake sediments, indicating POM degradation of sedimenting material (Carstens et al. 2012). Variation partitioning and linear model analysis showed that the CI also contributed significantly to explaining the variance of the particle-associated BCs and the total bacterial abundance. CI may be a particularly good indicator for the influence of organic matter on the abundance and composition of lacustrine bacteria since it is based on the degradation of chlorophyll and thus directly linked to the main source of degradable organic matter in the studied lakes, i.e. phytoplankton. Similarly, Rösel \& Grossart (2012) associated increased bacterial abundance following phytoplankton spring blooms with higher abundance of algal detritus.

In conclusion, the present study provides evidence that not only bulk environmental parameters like TOC, $\mathrm{O}_{2}, \mathrm{~T}$, and $\mathrm{pH}$, but also the concentration and quality of $\mathrm{POM}$, drive the abundance and composition of lacustrine BCs. The stronger temporal dynamics and the higher compositional variability of the particle-associated BCs compared to the free-living BCs fit well to previous long-term studies of particle-associated bacteria in temperate lakes (Rösel et al. 2012). Thus, future studies on the environmental factors shaping the vertical dynamics of lacustrine BCs should be analyzed on separated bacterial size fractions. We further recommend including the $\mathrm{CI}$ as a proxy for organic matter degradation state in future investigations on the ecology of lacustrine bacteria.

Acknowledgements. We are grateful to all the people who helped with sampling and chemical analysis: M. Schurter, A. Zwyssig, T. Wunderlin, T. Diem, G. Nobbe, L. Stojkovski, M. Kirf, B. Kienholz, R. Stierli, and R. Illi (Analytik- und Ausbildungslabor). We are grateful to F. Hammes for support with flow cytometry analyses. This study is part of an interdisciplinary project combining biogeochemistry and microbiology funded by the Swiss National Science Foundation (SNF, grants K-23Kl-118111 and 200020_134798) and the Swiss Federal Institute of Aquatic Science and Technology (Eawag). 


\section{LITERATURE CITED}

Allgaier M, Grossart HP (2006) Seasonal dynamics and phylogenetic diversity of free-living and particle-associated bacterial communities in four lakes in northeastern Germany. Aquat Microb Ecol 45:115-128

Allgaier M, Brückner S, Jaspers E, Grossart HP (2007) Intraand inter-lake variability of free-living and particle-associated Actinobacteria communities. Environ Microbiol 9: 2728-2741

Azam F, Fenchel T, Field JG, Gray JS, Meyer-Reil LA, Thingstad F (1983) The ecological role of water-column microbes in the sea. Mar Ecol Prog Ser 10:257-263

Bechtel A, Schubert CJ (2009) Biogeochemistry of particulate organic matter from lakes of different trophic levels in Switzerland. Org Geochem 40:441-454

- Beier S, Bertilsson S (2011) Uncoupling of chitinase activity and uptake of hydrolysis products in freshwater bacterioplankton. Limnol Oceanogr 56:1179-1188

Biddanda B, Opsahl S, Benner R (1994) Plankton respiration and carbon flux through bacterioplankton on the Louisiana shelf. Limnol Oceanogr 39:1259-1275

Borcard D, Gillet G, Legendre P (2011a) Forward selection of explanatory variables. In: Gentleman R, Hornik $\mathrm{K}$, Parmigiani GG (eds) Numerical ecology with R. Springer, New York, NY, p 175-180

Borcard D, Gillet G, Legendre P (2011b) Redundancy analysis. In: Gentleman R, Hornik K, Parmigiani GG (eds) Numerical ecology with R. Springer, New York, NY, p 153-170

> Carstens D, Schubert CJ (2012) Amino acid and amino sugar transformation during sedimentation in lacustrine systems. Org Geochem 50:26-35

Carstens D, Köllner KE, Bürgmann H, Wehrli B, Schubert CJ (2012) Contribution of bacterial cells to lacustrine organic matter based on amino sugars and D-amino acids. Geochim Cosmochim Acta 89:159-172

> Casamayor EO, Schäfer H, Bañeras L, Pedrós-Alió C, Muyzer G (2000) Identification of and spatio-temporal differences between microbial assemblages from two neighboring sulfurous lakes: comparison by microscopy and denaturing gradient gel electrophoresis. Appl Environ Microbiol 66:499-508

Crump BC, Kling GW, Bahr M, Hobbie JE (2003) Bacterioplankton community shifts in an Arctic lake correlate with seasonal changes in organic matter source. Appl Environ Microbiol 69:2253-2268

> Dauwe B, Middelburg JJ (1998) Amino acids and hexosamines as indicators of organic matter degradation state in North Sea sediments. Limnol Oceanogr 43: 782-798

> Dauwe B, Middelburg JJ, Herman PMJ, Heip CHR (1999) Linking diagenetic alteration of amino acids and bulk organic matter reactivity. Limnol Oceanogr 44: 1809-1814

- Davis J, Kaiser K, Benner R (2009) Amino acid and amino sugar yields and compositions as indicators of dissolved organic matter diagenesis. Org Geochem 40:343-352

Del Giorgio PA, Cole JJ, Cimbleris A (1997) Respiration rates in bacteria exceed phytoplankton production in unproductive aquatic systems. Nature 385:148-151

Dray S, Legendre P, Blanchet G (2009) packfor: forward selection with permutation (Canoco p.46). Available at http://R-Forge.R-project.org/projects/sedar/ (accessed 15 March 2011)
Eiler A, Bertilsson S (2007) Flavobacteria blooms in four eutrophic lakes: linking population dynamics of freshwater bacterioplankton to resource availability. Appl Environ Microbiol 73:3511-3518

> Fierer N, Jackson RB (2006) The diversity and biogeography of soil bacterial communities. Proc Natl Acad Sci USA 103:626-631

Fisher MM, Triplett EW (1999) Automated approach for ribosomal intergenic spacer analysis of microbial diversity and its application to freshwater bacterial communities. Appl Environ Microbiol 65:4630-4636

> Giroldo D, Henriques Vieira AA, Paulsen BS (2003) Relative increase of deoxy sugars during microbial degradation of an extracellular polysaccharide released by a tropical freshwater Thalassiosira sp. (Bacillariophyceae). J Phycol 39:1109-1115

> Grossart HP, Simon M (1998) Bacterial colonization and microbial decomposition of limnetic organic aggregates (lake snow). Aquat Microb Ecol 15:127-140

> Haake B, Ittekkot V, Ramaswamy V, Nair RR, Honjo S (1992) Fluxes of amino acids and hexosamines to the deep Arabian Sea. Mar Chem 40:291-314

> Hiorns WD, Methé BA, Nierzwicki-Bauer SA, Zehr JP (1997) Bacterial diversity in Adirondack mountain lakes as revealed by $16 \mathrm{~S}$ rRNA gene sequences. Appl Environ Microbiol 63:2957-2960

Jürgens K, Pernthaler J, Schalla S, Amann R (1999) Morphological and compositional changes in a planktonic bacterial community in response to enhanced protozoan grazing. Appl Environ Microbiol 65:1241-1250

Kent AD, Jones SE, Yannarell AC, Graham JM, Lauster GH, Kratz TK, Triplett EW (2004) Annual patterns in bacterioplankton community variability in a humic Lake. Microb Ecol 48:550-560

Kent $\mathrm{AD}$, Jones SE, Lauster GH, Graham JM, Newton RJ, McMahon KD (2006) Experimental manipulations of microbial food web interactions in a humic lake: shifting biological drivers of bacterial community structure. Environ Microbiol 8:1448-1459

Kindt R, Coe R (2005) Tree diversity analysis: a manual and software for common statistical methods for ecological and biodiversity studies. World Agroforestry Centre (ICRAF), Nairobi

Köllner KE, Carstens D, Keller E, Vazquez F, Schubert CJ, Zeyer J, Bürgmann H (2012) Bacterial chitin hydrolysis in two lakes with contrasting trophic statuses. Appl Environ Microbiol 78:695-704

> Langenheder S, Jürgens K (2001) Regulation of bacterial biomass and community structure by metazoan and protozoan predation. Limnol Oceanogr 46:121-134

> Lee C, Cronin C (1984) Particulate amino acids in the sea: effects of primary productivity and biological decomposition. J Mar Res 42:1075-1097

Legendre P, Gallagher ED (2001) Ecologically meaningful transformations for ordination of species data. Oecologia 129:271-280

Lindström ES (2000) Bacterioplankton community composition in five lakes differing in trophic status and humic content. Microb Ecol 40:104-113

> Lindström ES (2001) Investigating influential factors on bacterioplankton community composition: results from a field study of five mesotrophic lakes. Microb Ecol 42: 598-605

Lindström ES, Kamst-Van Agterveld MP, Zwart G (2005) Distribution of typical freshwater bacterial groups is 
associated with $\mathrm{pH}$, temperature, and lake water retention time. Appl Environ Microbiol 71:8201-8206

- Meckler AN, Schubert CJ, Cowie GL, Peiffer S, Dittrich M (2004) New organic matter degradation proxies: valid in lake systems? Limnol Oceanogr 49:2023-2033

Methé BA, Zehr JP (1999) Diversity of bacterial communities in Adirondack lakes: Do species assemblages reflect lake water chemistry? Hydrobiologia 401:77-96

> Newton RJ, Jones SE, Eiler A, McMahon KD, Bertilsson S (2011) A guide to the natural history of freshwater lake bacteria. Microbiol Mol Biol Rev 75:14-49

Oksanen J, Blanchet FG, Kindt R, Legendre P and others (2011) vegan: community ecology package. In: R Package Version 2.14-0 http://CRAN.R-project.org/package= vegan

Parveen B, Reveilliez JP, Mary I, Ravet V and others (2011) Diversity and dynamics of free-living and particle-associated Betaproteobacteria and Actinobacteria in relation to phytoplankton and zooplankton communities. FEMS Microbiol Ecol 77:461-476

Peres-Neto PR, Legendre P, Dray S, Borcard D (2006) Variation partitioning of species data matrices: estimation and comparison of fractions. Ecology 87:2614-2625

Peter H, Beier S, Bertilsson S, Lindström ES, Langenheder S, Tranvik LJ (2011) Function-specific response to depletion of microbial diversity. ISME J 5:351-361

Ramette A (2007) Multivariate analyses in microbial ecology. FEMS Microbiol Ecol 62:142-160

Ramette A (2009) Quantitative community fingerprinting methods for estimating the abundance of operational taxonomic units in natural microbial communities. Appl Environ Microbiol 75:2495-2505

R Development Core Team (2009) R: a language and environment for statistical computing. R Foundation for Statistical Computing, Vienna. Available at www.Rproject.org

Roiha T, Tiirola M, Cazzanelli M, Rautio M (2011) Carbon quantity defines productivity while its quality defines community composition of bacterioplankton in subarctic ponds. Aquat Sci 74:513-525

Rösel S, Grossart HP (2012) Contrasting dynamics in activity and community composition of free-living and particleassociated bacteria in spring. Aquat Microb Ecol 66: 169-181

Rösel S, Allgaier M, Grossart HP (2012) Long-term characterization of free-living and particle-associated bacterial communities in Lake Tiefwaren reveals distinct seasonal patterns. Microb Ecol 64:571-583

Salcher MM, Pernthaler J, Posch T (2011) Seasonal bloom dynamics and ecophysiology of the freshwater sister clade of SAR11 bacteria that rule the waves (LD12). ISME J 5:1242-1252

Salcher MM, Posch T, Pernthaler J (2012) In situ substrate preferences of abundant bacterioplankton populations in a prealpine freshwater lake. ISME J, doi:10.1038/ismej. 2012.162

Editorial responsibility: Klaus Jürgens,

Rostock, Germany
Schubert CJ, Niggemann J, Klockgether G, Ferdelman TG (2005) Chlorin index: a new parameter for organic matter freshness in sediments. Geochem Geophys Geosyst 6: Q03005, doi:10.1029/2004GC000837

> Shade A, Jones SE, McMahon KD (2008) The influence of habitat heterogeneity on freshwater bacterial community composition and dynamics. Environ Microbiol 10: 1057-1067

Sherr EB, Sherr BF (1991) Planktonic microbes: tiny cells at the base of the ocean's food webs. Trends Ecol Evol 6: 50-54

Šimek K, Pernthaler J, Weinbauer MG, Horňák K, and others (2001) Changes in bacterial community composition and dynamics and viral mortality rates associated with enhanced flagellate grazing in a mesoeutrophic reservoir. Appl Environ Microbiol 67:2723-2733

Šimek K, Kasalický V, Zapomĕlová E, Horňák K (2011) Alga-derived substrates select for distinct betaproteobacterial lineages and contribute to niche separation in Limnohabitans strains. Appl Environ Microbiol 77 : 7307-7315

Siuda W, Chróst RJ (2002) Decomposition and utilization of particulate organic matter by bacteria in lakes of different trophic status. Pol J Environ Stud 11:53-65

Smith DC, Simon M, Alldredge AL, Azam F (1992) Intense hydrolytic enzyme activity on marine aggregates and implications for rapid particle dissolution. Nature 359: 139-142

Van Der Gucht K, Sabbe K, De Meester L, Vloemans N, Zwart G, Gillis M, Vyverman W (2001) Contrasting bacterioplankton community composition and seasonal dynamics in two neighbouring hypertrophic freshwater lakes. Environ Microbiol 3:680-690

Venables WN, Ripley BD (2002) Modern applied statistics with S, 4th edn. Springer, New York, NY

Vogler P (1965) Beiträge zur Phosphatanalytik in der Limnologie. Fortschr Wasserchem Grenzgeb 2:109-119

- Yannarell AC, Triplett EW (2004) Within- and between-lake variability in the composition of bacterioplankton communities: investigations using multiple spatial scales. Appl Environ Microbiol 70:214-223

> Yannarell AC, Triplett EW (2005) Geographic and environmental sources of variation in lake bacterial community composition. Appl Environ Microbiol 71:227-239

> Yannarell AC, Kent AD, Lauster GH, Kratz TK, Triplett EW (2003) Temporal patterns in bacterial communities in three temperate lakes of different trophic status. Microb Ecol 46:391-405

Zeng J, Bian Y, Xing P, Wu QL (2012) Macrophyte species drive the variation of bacterioplankton community composition in a shallow freshwater lake. Appl Environ Microbiol 78:177-184

> Zwart G, Crump BC, Kamst-van Agterveld MP, Hagen F, Han SK (2002) Typical freshwater bacteria: an analysis of available 16S rRNA gene sequences from plankton of lakes and rivers. Aquat Microb Ecol 28:141-155

Submitted: July 9, 2012; Accepted: February 28, 2013

Proofs received from author(s): April 15, 2013 